\title{
Dåpssamtalen i en ny tid
}

\author{
Av Runar J. Liodden \\ Runar Johannessen Liodden, f. 1974, kapellan i Modum menighet, Kapellveien 1, 3340 Åmot \\ E-post: runar.liodden@modumkirke.no
}

\section{INNLEDNING}

For 50 år siden ble $97 \%$ av alle nyfødte i Norge døpt inn i Den norske kirke. I fjor ble $62 \%$ av alle norske barn døpt i folkekirken. Flere mener at dåpstallene vil fortsette å gå nedover. Hvordan møter kirken de ulike foreldrene som i dag velger kristen dåp for barnet sitt? Etter at dåpshandlingen er gjennomført, reiser foreldrene seg sammen med fadderne og får høre de samme ordene av presten: "Dere er vitner om at barna er døpt med den kristne dåp. Sammen med vår menighet og hele kirken har dere fått del $i$ et hellig ansvar: å vise omsorg for dem, be for dem, lare dem selv å be og hjelpe dem til å bruke Guds ord og delta i den hellige nattverd, så de kan leve og vokse i den kristne tro." Uttrykker denne formuleringen et press til å gjøre noe foreldre og faddere ikke er klare for? Eller kan prestens ord skape en motivasjon til å gå i gang med oppgaven?

I forkant av dåpen $\mathrm{i}$ en gudstjeneste har presten eller en av de kirkelig ansatte en samtale med foreldrene. De første planmessige forsøkene i Norge med slike samtaler ble gjennomført på 60-tallet. Fra Bispemøtets utredning Dåpspraksis og dåpsopplcering $i$ Den norske kirke i 1982 blir dåpssamtalen forstått som den vanlige praksisen i menighetene. Tradisjonelt har prestene hatt eneansvaret for samtalene, men flere steder har også kateketer gjennomført samtaler med dåpsforeldrene.

Jeg har vært prest i Modum menighet de siste 13 årene. Ytterst få av dåpssamtalene har vært med foreldre som har en avklart kristen tro og er ivrige med å gi troen videre til sine barn. Det store flertallet er enten foreldre som er positive til menigheten i lokalsamfunnet og har gode erfaringer med kveldsbønn og søndagsskole, eller foreldre som viderefører en tradisjon, men er skeptiske til å påvirke barnet med religiøst innhold. I mange år gruet jeg meg til samtalene på grunn av den store avstanden mellom hva vår kirke ønsker for dåpsforeldrene og hva de selv er opptatt av. Nå kjenner jeg en større trygghet i møte med denne utfordringen. Jeg vil i denne praksisartikkelen dele flere av refleksjonene jeg har gjort meg i møte med dåpsforeldrene, og redegjøre for hvilke grep jeg har testet ut for å kommunisere godt med ulike foreldre. Jeg har hatt flere samtaler med både tenåringer og voksne i forkant av sin dåp, men ettersom det store flertallet av dåpssamtaler er med foreldre til småbarn, er det denne gruppen jeg fokuserer på her.

\section{PÅVIRKNING MED RESPEKT?}

Hvordan møter vi foreldre som har et ulikt forhold til troen og dåpen? Den danske pedagogen Carsten Hjort Pedersen beskriver i boka "Påvirkning med respekt" (Hjort Pedersen 2008: 39-49) en pedagogisk modell som er beregnet på den asymmetriske relasjonen mellom voksen og barn i hjem og skole. Jeg finner modellen både nyttig og overførbar til den asymmetriske relasjonen i dåpssamtalen, mellom prest og dåpsforeldre. Hjort Pedersen presenterer to grøfter samspillet kan ende i. Den ene grøfta kaller han intimisering. Dette oppstår når vi blir 
for nærgående, invaderende og påprakkende i forholdet til den andre. Den andre grøfta betegner han som desertering, hvor avstanden blir for stor og man kan oppfattes som kjølig og likegyldig av den andre. En deserterende dåpssamtale kan være en samtale som kun fokuserer på den praktiske forberedelsen til dåpen og gudstjenesten, men utelater å snakke om forståelse av dåpen og forventningene til oppdraget etter dåpen. Intimisering skjer når presten krenker foreldrenes valgfrihet og for eksempel beordrer foreldrene å be for barnet sitt hver kveld. Den fruktbare veien å gå handler for Hjort Pedersen om å kombinere konfrontasjon og tilbaketrekking. Konfrontasjonen i dåpssamtalen kan være å oppmuntre foreldrene til å gjøre konkrete trospraksiser sammen med barnet på hjemmebane og invitere dem til babysang. Tilbaketrekking er holdningen hvor foreldrene får rom til å avgjøre selv hvordan de vil følge opp etter dåpen. Det er foreldrene som er ansvarlig for oppdragelsen av barnet sitt.

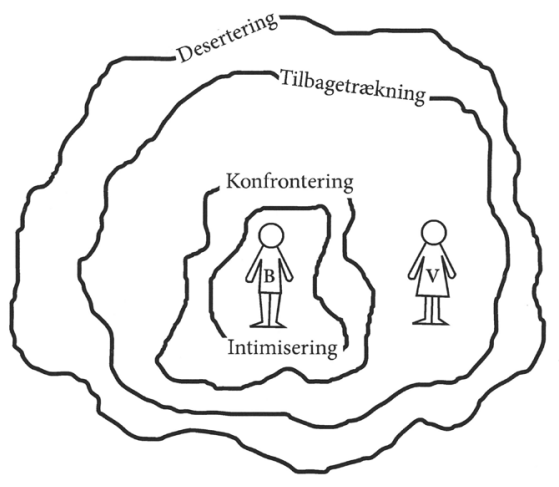

Hjort Pedersen har laget en visuell framstilling av denne pedagogiske modellen. (Hjort Pedersen 2008: 47.) Som tegningen over viser, er det ikke jevne sirkler rundt personen i sentrum. De ujevne rundingene er ment å uttrykke at avstand og nærhet oppleves ulikt. For en pappa kan oppmuntringen til å tegne korsets tegn over barnet sitt daglig oppleves påprakkende, mens foreldrene i en annen samtale er mer mottagelig for en slik oppmuntring. Av den grunn er det avgjørende å skape en dialog med foreldrene som sikrer at de tør å gi en respons på prestens konkrete forslag.

Kommunikasjonen med dåpsforeldrene påvirkes også av rammebetingelsene for samtalen. De kirkelig ansatte legger føringene blant annet for hvor samtalen skal foregå. Hvilken arena er best egnet til å kombinere konfrontasjon og tilbaketrekking? Prestens kontor, menighetssalen eller hjemme hos dåpsforeldrene?

Den svenske kommunikasjonseksperten Eva Reimers ble hentet inn som en ressursperson i 2002 da prosjektet «Inn i kirken - med dåpssamtalen som utgangspunkt» ble initiert $\mathrm{i}$ Den norske kirke. Reimers fokuserte blant annet på rammebetingelsene for samtalen. Hun skiller mellom en truende innramming og en ikke-truende innramming av samtalen. Noen prester foretrekker å møte dåpsforeldrene på sitt eget kontor, gjerne plassert bak skrivebordet. Andre drar helst hjem til foreldrene og sier ja takk til en kopp kaffe under samtalen. Mange foreldre opplever situasjonen mindre truende når de befinner seg på hjemmebane. På den andre siden kan de oppleve situasjonen som svært beklemmende hvis presten overkjører dem når de møter ham eller henne alene. Reimers understreket likevel at de fleste foreldre opplever det mest positivt å være alene om dåpssamtalen, fremfor å samtale $\mathrm{i}$ en gruppe med flere foreldrepar. De føler at de blir mer sett når de møter presten alene. Førstelektor ved NLA Høgskolen i Bergen, Rune Øystese, støtter dette i Prismet 3/2013: "Når det møter flere foreldrepar i grupper, kan det være lett å overse at forskjellige foreldre har forskjellige behov. Den personlige samtalen gir større mulighet til åpenhet og fortrolighet enn gruppesamtalene." 
Mange menigheter satser nå på større gruppesamlinger hvor flere ansatte medarbeidere er med. Et slikt grep reduserer tida de ansatte bruker på dåpssamtalene, som igjen frigir tid til andre viktige oppgaver. Videre ser man en fordel $i$ at foreldrene møter de som har ansvaret for babysang og andre trosopplæringstiltak. Det personlige møtet med trosopplærer vil gjerne motivere sterkere til deltagelse på babysang i forhold til å få en infolapp om tilbudet i dåpssamtalen på hjemmebane. Presten og de andre ansatte er fagpersoner og ledere for menigheten hvor barnet skal døpes. Når de inviterer foreldrene som gjester til sin hjemmebane, vil dette forsterke asymmetrien. Men hvis menigheten inviterer mange dåpsforeldre til en felles samling i kirken, vil asymmetrien kunne dempes noe fordi dåpsforeldrene er i flertall. Likevel er dåpsforeldrene gjester, og relasjonene foreldrene imellom er sjelden så nære at de vil kjenne på en gruppetilhørighet.

Hjemme hos dåpsfamilien er derimot foreldrene de kjente og erfarne, mens presten er gjest. Dette kan bidra til å redusere asymmetrien som preger relasjonen mellom presten og foreldrene. Dette skaper bedre rammer for en åpen og ekte dialog hvor foreldrene kan dele positive og negative erfaringer med menigheten eller utfordringer $i$ forbindelse med familieforøkelsen. Hjemmet er dessuten hovedarenaen for foreldrenes oppdrag etter dåpen. Å ha lest en bibelfortelling eller snakket om å synge kveldsbønn i hjemmet bygger en bro til at foreldrene kan gjøre det på egenhånd. Hvis alle innspill blir gitt fra prestens egen hjemmebane, kan dette oppleves som om oppdraget etter dåpen hører hjemme kun i den religiøse delen av livet vi lever i kirkebygningen.

På bakgrunn av disse refleksjonene mener jeg at foreldrenes hjemmebane gir de beste rammer for å balansere en konfronterende og tilbaketrekkende kommunikasjon med foreldrene.
HVA SKAL DÅPSSAMTALEN

INNEHOLDE?

Den norske kirke har ingen felles mal eller konkret veiledning for hva som skal tas opp $i$ dåpssamtalen. Den enkelte prest er fri til å prege dåpssamtalen etter sitt eget skjønn. Dette skaper muligheten for en tilpasset og personlig dåpssamtale med det unike foreldreparet. På den annen side medfører friheten at de kirkelig ansatte eksempelvis kan redusere samtalen til kun å gjelde informasjon om det som skal skje i gudstjenesten.

I min prestetjeneste har jeg hatt en trefoldig hensikt med dåpssamtalen.Jeg ønsker for det første å forberede foreldrene til dåpshandlingen. For det andre vil jeg gjerne hjelpe foreldrene til å bedre forstå hva dåpen handler om. Til slutt sikter jeg mot å motivere foreldrene til å ta fatt på oppdraget sammen med faddere og lokalmenigheten med positiv forventning. Herunder vil jeg presentere disse hensiktene nærmere med størst vekt på den tredje hensikten.

\section{HENSIKT 1: Å FORBEREDE FORELDRE- NE TIL DÅPSHANDLINGEN}

Målet med dette er å gjøre foreldrene trygge på sin rolle i gudstjenesten og det som skjer ved dåpen. Foreldre har et naturlig behov for å vite når de skal møte i kirken, hvem som deltar $\mathrm{i}$ inngangsprosesjonen, hvor de så skal sitte, når de skal reise seg, hva de skal svare ved døpefonten og når de skal svare. Jeg går grundig igjennom gangen i dåpen og forklarer konkret og tydelig hva jeg tar ansvar for og hva de skal gjøre. Samtidig understreker jeg at jeg ikke forventer at de skal huske alt, men poengterer enkelte ting som er viktig å merke seg. Ofte deler jeg noen artige situasjoner som har oppstått tidligere, for å vise at jeg har et avslappet forhold til misforståelser som kan oppstå og at jeg har god erfaring med å løse dem der og da. Jeg gir dem også muligheter til å spørre om ting de lurer på, og deler gjerne konkrete, praktiske tips som har fungert godt for 
andre dåpsforeldre. Dette skaper trygghet som også gjør foreldrene mer åpne for de to andre hensiktene.

\section{HENSIKT 2: Å HJELPE FORELDRENE TIL Å FORSTÅ HVA SOM SKJER}

\section{DÅPEN}

Denne hensikten innebærer å gi foreldrene en forståelse av at dåpen åpner opp for et liv som et elsket barn i Guds familie og gir barnet en tilhørighet til den korsfestede og oppstandne Jesus Kristus. De færreste foreldrene er klare for et teologisk foredrag i samtalen. Men ettersom teologien er integrert i liturgien, er det mange muligheter til å formidle teologien mens jeg tar den praktiske gjennomgangen. Eksempelvis gjenforteller jeg teksten om Jesus og barna fra Markus 10 som leses før dåpen. Å høre at Jesus ble sinna på disiplene sine når de avviste barna, formidler at barna er verdifulle for Jesus. Et annet eksempel er at når jeg forteller om korstegningen før dåpen, så omtaler jeg korset som logoen til den kristne tro. Ofte jobber en av foreldrene på en arbeidsplass med en egen logo eller er med i idrettsforening. Logoen viser hvor vi hører hjemme, slik korsets tegn understreker den døptes tilhørighet til Jesus Kristus. Jeg kommer videre tilbake til tilhørigheten når jeg orienterer om praksisen med å vise fram dåpsbarnet etter dåpen. Jeg spør om jeg kan løfte opp barnet $\mathrm{i}$ gudstjenesten for å vise at nå har barnet fått en større familie, en tilhørighet til menigheten og Guds familie, som jeg representerer som prest. På denne måten knyttes teologi og praktiske detaljer sammen. Den praktiske gjennomgangen er alle foreldre motivert for å lytte til. Det er lettere å skape forståelse hos foreldrene når teologien knyttes til det vi skal gjøre. Når vi da gjennomfører i praksis det vi snakket om i dåpssamtalen, får foreldrene en repetisjon av teologien som styrker muligheten for at de har fått en større forståelse av hva dåpen er.

\section{HENSIKT 3: Å MOTIVERE \\ FORELDRENE TIL OPPDRAGET ETTER DÅPEN}

Foreldre har som tidligere nevnt svært ulikt utgangspunkt i forhold til den kristne tro. Men en ting har alle foreldre felles - de påvirker og preger barnet sitt. Valgfriheten til foreldre handler ikke om hvorvidt de vil påvirke, men hva de påvirker til og hvordan. I dåpssamtalen mener jeg det er avgjørende å motivere foreldrene til å ta del $\mathrm{i}$ lokalmenighetens trosopplæringstiltak og gi rom for at opplæringen i den kristne tro også skjer på hjemmebane i hverdagen.

Jeg vil i det følgende dele noen flere erfaringer med det å praktisere kombinasjonen av konfrontasjon og tilbaketrekking i møte med svært ulike foreldre.

\section{Realitetsorientering}

Skolen var tidligere Den norske kirkes nære allierte når det gjaldt opplæring i den kristne tro. Selv om skolen sa fra seg dette oppdraget i 1969, åpnet læreren min skoledagene på 80-tallet med salmesang, og avsluttet med Fader vår. Kristendomsfaget fulgte oss gjennom hele grunnskolen, men med innføringen av KRLfaget i 1997 og RLE-faget i 2008 ble det tydelig at skolens bidrag til kristen opplæring av de døpte i Den norske kirke er betraktelig redusert.

Jeg pleier noen ganger å illustrere forskjellen i opplæring med et tenkt eksempel fra de store lagidrettene. Tidligere hadde fotball en dominerende rolle i skolen. Selv om fotballen fortsatt har størst plass i idrettsfaget, skal barna nå også lære om de andre store lagidrettene. Den store forskjellen er at det nå er forbudt å spille fotball og andre lagidretter på skolen. Elevene ser bilder av kjente baner og spillere gjennom historien. De lærer spillereglene, men får ikke spille fotball, volleyball eller basketball. Hvilken erfaring og kjennskap får de av fotball ved å se på bilder, men aldri berøre en ball med foten, 
aldri spille på et lag? Svært mangelfullt. Skolens ansvar er å gi informasjon, mens foreldrene nå selv, sammen med sitt idrettslag, må ta ansvar for å gi barnet sitt praktiske erfaringer i fellesskap med andre og en dypere kjennskap til lagidretten $\sin$.

Dagens foreldre trenger å se at verken skole eller barnehage ivaretar oppdraget som de har fått ved dåpen. Når barna ikke lærer Herrens bønn utenat i barnehagen eller på skolen, trenger barna å få denne erfaringen andre steder.

\section{Å velge selv}

Mange foreldre gir uttrykk for at barnet må få velge selv hva det vil tro på. En slik tankegang henger ofte sammen med å være tilbakeholden med religiøs påvirkning. Men jeg prøver ofte å formidle til dåpsforeldre at en slik holdning kan påvirke barnet like sterkt som dersom foreldre leser bibelfortellinger og ber sammen med barnet sitt daglig. Barn av tilbakeholdne foreldre vil sannsynligvis oppfatte gudstroen i stedet som noe uinteressant eller fjernt. Ut $\mathrm{i}$ fra modellen til Hjort Pedersen vil dette kunne beskrives som desertering. Barnet vil uansett ta et eget valg når det vokser opp. Foreldreansvaret handler om å gi dem muligheten til å ta et eget valg. Og ettersom ingen velger noe en ikke kjenner, trenger de unge som blir døpt å få erfaringer og kjennskap til den kristne tro, som istandsetter dem til å ta et eget valg. Dette er en påvirkning som viser barnet respekt.

Ved å formidle et slikt perspektiv, ønsker jeg å hjelpe foreldrene til å innse at de påvirker barnet uansett hva de gjør, samtidig som at påvirkningen ikke hindrer barna i å ta et eget valg seinere.

\section{Foreldrene er de viktigste}

Alle landets menigheter har nå tatt del i den storstilte trosopplæringsreformen i Den norske kirke. Lokalmenigheter inviterer foreldre og barn til ulike trosopplæringstiltak i alderspennet 0-18 år. Utdeling av 4-årsboka er nok tiltaket med lengst historie, men de siste årene har Tårnagenthelg og LysVåken etablert seg som gode, årlige møteplasser i menighetene. Forsker Ida Marie Høeg ved Kifo har vurdert fire menigheters trosopplæringsarbeid og sier dette: "Tilnærmingen (i trosopplæringen) overskygger det faktum at foreldre, besteforeldre og andre pårørende kan drive trosopplæring i hjemmet for sine barn selv. Trosopplæring innebærer ikke nødvendigvis å ta særlig mye del i kirkens tilbud. I foreldrenes kontakt med kirken kunne kirken vært mindre opptatt av familienes deltakelse i kirken og desto mer opptatt av å styrke foreldre der de er; i familiene." (Lannem/StifossHansen. 2006: 80.)

Poenget til Høeg er ikke å underkjenne betydningen av menighetens trosopplæringsarbeid, men i større grad å anerkjenne foreldrene som de viktigste trosopplærerne for barnet sitt. Foreldre står i en særstilling til sine barn. Ingen andre personer har en mer åpen og tillitsfull relasjon til deres barn. Det kan være spennende å høre fortellingen om den blinde Bartimeus som får synet igjen av Jesus på en familiegudstjeneste, men det kan ikke måle seg opp mot å sitte i armkroken til pappa eller på fanget til mamma å høre den samme fortellingen. Den kjente stemmen, hjemmet der man er trygg, muligheten til å stille ærlige spørsmål og ha en samtale i etterkant er verdifulle kvaliteter som gir barnet en større nærhet til fortellingen. Menigheten kan heller ikke konkurrere med foreldrene i mengden tid de har sammen med barnet.

Når foreldre er usikre og uerfarne med å formidle kristen tro, mener jeg det er avgjørende at ikke kirken møter dem med holdningen: "Kom til oss, vi kan dette. Overlat ansvaret til oss!” I stedet virker det viktig å støtte foreldrene og gjøre dem trygge på at de er tilstrekkelig kompetente til å ta dette ansvaret. 


\section{EN HELT OVERKOMMELIG TROSOPPLÆRING?}

Etter dåpshandlingen sier presten, som jeg nevnte i starten av artikkelen: "Sammen med vår menighet og hele kirken har dere fått del $i$ et hellig ansvar: å vise omsorg for ham, be for ham, lare ham selv å be og hjelpe ham til å bruke Guds ord og delta $i$ den hellige nattverd, så han kan leve og vokse i den kristne tro." Vil de fleste foreldre forstå oppdraget sitt ut ifra slike formuleringer? Hverdagen til familier er ofte hektisk enten det er en alenemor, en tradisjonell kjernefamilie eller en familie med dine, mine og våre barn. Når begge foreldrene jobber og ungene er aktive utenom skole og barnehage, risikerer menigheten å øke presset ytterligere på familien. Hva er realistisk å motivere dem til å gjøre?

Dåpssamtalen gir en sjelden mulighet til å konkretisere hva familien kan gjøre på hjemmebane. Jeg vektlegger selv fire praksiser: Å synge eller be en kveldsbønn, å tegne korsets tegn, lese bibelfortellinger og feire dåpsdagen.

Å feire dåpsdagen er overkommelig ettersom den skjer kun årlig og blir en noe høytidelig påminnelse om at barnet er døpt. På bakgrunn av egne erfaringer pleier jeg å presentere en mulig måte å feire på, men understreker samtidig at familien selv kan utforme sin egen tradisjon med feiring av dåpsdagen. Å lage en ekstra koselig dag med en middag og en dessert som barnet har valgt, tenne dåpslyset, se på bilder og film fra dåpen, snakke om hvem som er fadderne til barnet, er noe jeg opplever de aller fleste er motivert til å gjøre.

$\AA$ tegne barnet med korsets tegn anbefaler jeg sammen med en kveldsbønn som en daglig, god vane. Samtidig med å tegne korsets tegn foreslår jeg å si: ”Hø-rer Je-sus til!” Dette gir barnet en erfaring av bønn og en påminnelse av at dåpen har gitt barnet en tilhørighet til Jesus. Rent tidsmessig er dette overkommelig. De fleste uttrykker en velvilje overfor å synge Kjære Gud jeg har det godt eller en annen kveldsbønn, men å tegne korsets tegn er for de fleste dåpsforeldre noe nytt og uvant. Likevel er mange positive til å gjøre det.

Videre oppmuntrer jeg å lese bibelfortellinger for barna. Rent konkret leser jeg en fortelling fra en barnebibel for foreldrene i samtalen for å gi dem en opplevelse av hvordan det kan gjøres. Mange vet ikke hva en barnebibel er, og flertallet gir en klar positiv respons på å lese fortellinger med bilder og et enkelt språk for barnet sitt.

Jeg oppsummerer til slutt for de ulike foreldrene at disse konkrete praksisene vil legge til rette for gode stunder sammen, med nærhet, blikkontakt og samtale. I tillegg forsøker jeg å motivere dem til å gå i gang med praksisene uavhengig av tro og tidligere erfaringer. Man trenger ikke en teologisk utdannelse eller en sterk tro for å gjennomføre dette. Det handler om å synge eller si en konkret sang, gjøre en konkret bevegelse, lese fra en konkret bok og tenne et konkret lys på dåpsdagen. For meg er det også et poeng at slike trospraksiser kan bidra til at det kan vokse fram en mer avklart kristen tro hos foreldrene. De er blitt utrustet med noe konkret og overkommelig som de har evne og tid til å gjennomføre på hjemmebane.

Når jeg oppmuntrer foreldrene til å gjøre disse trospraksisene hjemme, representerer dette konfrontasjonen i Hjort Pedersens modell. Etterpå inviterer jeg dem til å respondere på hva de selv tenker om å gjøre dette: ”Nå har jeg snakket mye. Dere er foreldrene til Kristian. Dere bestemmer hva dere vil gjøre! Hva tenker dere om å gjøre dette her hjemme? Hvordan opplever dere at jeg kommer med slike forslag?"

Når jeg åpner for en dialog med foreldrene og understreker friheten de har til selv å velge hvordan de vil følge opp oppdraget, opplever jeg å ivareta tilbaketrekkingen i samme modell. 
OPPSUMMERING

Carsten Hjort Pedersen har utarbeidet en pedagogisk modell som er nyttig å bruke i dåpssamtalen mellom kirkelig ansatte og dåpsforeldre. Intimisering og desertering representerer grøftene, mens målet er den respektfulle påvirkningen som skjer i kombinasjon av konfrontasjon og tilbaketrekking. Jeg har presentert den trefoldige hensikten jeg ser med dåpssamtalen, og delt praksiseksempler og refleksjoner over hvordan en kan nå målene for samtalene på en måte som kan forstås som respektfull påvirkning.
LITTERATUR

Hjort Pedersen, Carsten. 2008. Påvirkning med respekt. København: Gyldendal.

Lannem, Turid Skorpe og Stifoss-Hansen, Hans. 2006. Metode, mål og mening $i$ Den norske kirkes trosopplaringsreform. Trondheim: Tapir Akademisk Forlag.

www.kirken.no. Kirkeinfo 260202. Prosjekt dåpssamtale.

Øystese, Rune. 2013. Dåpssamtalen, en suksesshistorie? Prismet, 3/64: 155-171. 